\title{
Intellectualizing religion in the cities of the Roman Empire
}

\begin{abstract}
This essay examines early Christian literature as evidence for a trend in religious movements with an increasingly literary or otherwise intellectual profile. Self-proclaimed authorities on Christ clustered in the urban spaces of the empire where they joined and rivaled assorted aspiring specialists who boasted a range of skills and, in some cases, derived wisdom or mysteries from the same writings. All partook in a broader phenomenon of religious innovation that was propelled by urban resources: the book industry, a growth in libraries, the heightened status of writings, and a widespread enthusiasm for paideia. I argue that Christian authors are prime, if unexceptional, examples of this more general religious development. Thus situated, their writings hold important clues for theorizing the activities of non-Christian religious actors and groups that are less well attested in this early period.
\end{abstract}

\section{Introduction}

In the first book of his Against the Heresies (Haer. 1.7.1-2), Irenaeus denounces Marcus, a follower of Valentinus, as a "skilled magical imposter" (magicae imposturae peritissimus) who deceived many with his apparent ability to work wonders. The tricks that Irenaeus attributes to Marcus-altering the color of a cup of wine to give the impression of an efficacious invocation, for instance-are well known; less so, perhaps, their alleged source, the Paignia of Anaxilaus, a figure known variously from earlier sources as a physician, a Pythagorean philosopher, a magician, and the author of several writings about the "magical" properties of minerals, herbs, and other natural materials. ${ }^{1}$ These paignia, Irenaeus reports, Marcus combined with the wickedness of those called magi as well as a smattering of Christian texts to achieve his proprietary heretical brew, one that proved especially intoxicating to wealthy women.

Irenaeus's tone, equal parts derisive and hyperbolic, has led many a translator to render paignia as buffooneries or tricks, with the implication that Marcus traded in cheap magicians' gimmicks; there can be little doubt that the heresiologist understood Anaxilaus and his legacy in such terms. However, this lan-

1 See, e.g., Pliny, Nat. 19.19-20, 25.10, 154, 28.180, 32.141, 35.175.

Ә OpenAccess. () 2020 Laetzer/Urciuoli, published by De Gruyter. (cc) BY-NC-ND This work is licensed under the Creative Commons Attribution-NonCommercial-NoDerivatives 4.0 License. 
guage points in a more specific direction, namely, to Marcus's possession of a technical manual intended for practical application. A woman named Salpe, whom, like Anaxilaus, a handful of Greco-Roman authors connect with knowledge about the special properties of natural substances, was the putative author of a work on the topic known by the same title. ${ }^{2}$ The term paignia also appears in the Greek Magical Papyri as the heading for twelve remedies and tricks ascribed to Democritus that require little skill and access to only mundane ingredients. ${ }^{3}$ Comparing the respective paignia of Salpe and Democritus, James N. Davidson (1994, 592) remarks that both collections seemed to have shared the distinctive quality of simplicity, "which provides a stark contrast with the usual convoluted procedures and dense formulaic complexity of ancient medicine and magic." This language, he concludes, evoked not mean tricks or nonsense per se, but an easy task or “child's play." In such literary contexts, paignia served as a title for the wisdom or spells or pharmaka or divinatory techniques of some renowned sage; a how-to manual of sorts, for beginners.

Marcus's alleged consultation of the Paignia of Anaxilaus is but one of many indications that Christian authors of the second century participated in a literary landscape that encompassed many more writings than Jewish and Christian scripture. On the one hand, there is nothing surprising about this observation. It is well known that our earliest "Christian" author, the apostle Paul, was well versed in contemporary philosophy, as were some, if not all, of the authors of the (later) canonical gospels and certainly those of many non-canonical writings and heresiological literature. On the other, we are only beginning to appreciate how thoroughly certain Christians were imbricated in this fuller literary matrix. Their writings do not merely reflect the general intellectual climate of the day but also exhibit active, often technical engagement with specific sources. ${ }^{4}$ Of course, one might conclude that, as in the case of Marcus or his philosophically attuned Valentinian associates, such textual dalliances were an index of heretical tendencies, but this conclusion would overlook the larger point that literate Christians on either side of the "orthodoxy" divide were both highly aware and made ample, if varied, use of assorted writings available to them. Likewise, the character, form, and purpose of their literary activities matched those of contemporaneous social actors, particularly ones who aspired to some form of religious or intellectual expertise.

2 FGrHist 572 F 5; Athenaeus, 7.322a; Pliny, Nat. 28.18, 23, 38, 66, 82, 262, 32.135, 140.

3 For discussion, including a possible connection between Paignia of Democritus and Anaxilaus, see Dickie 2001, 118-19.

4 For example, the author known as Hippolytus of Rome's extensive engagement with astrological texts and epistemologies (Berzon 2016, 98-126). 
This volume's focus on ancient cities as sites of religious activity furnishes an opportunity to consider not only the range of religious institutions and materially attested spaces that comprised urban topographies-everything from monumental temples to mithraea and other gathering places for voluntary associations to household shrines-but also more ephemeral religious social formations that cities supported. If one of our emphases is on how religion contributed to or promoted socio-spatial and temporal order in the cities of the Roman world, I wish to approach our topic from another perspective. I am more interested in their comparatively disordered spaces, those that existed between religious activities that unfolded in institutions funded by the state and overseen by regular personnel, and the largely symmetrical, if flexible, practices of domestic cult. For cities of the empire served not only as sites for articulating relations of power and order, new civic statuses, and so forth, but also as especially wellequipped theaters of possibility for aspiring specialists lacking institutional affiliation, who capitalized on particular features of their urban environments to claim other modes of distinction and legitimacy.

Our appreciation for the interests, tactics, and impact of these self-authorized or freelance religious experts has grown considerably in the last decades as the result of a growing interest in the contributions of individual agents to other currents of religious diversity and change occurring under the empire (Rüpke and Spickermann, 2012; Rüpke 2013). Interestingly, if unsurprisingly, the methodological reorientation that has occurred for other subsets of religion in the Roman world has had less of an impact on the study of early Christianity, which remains primarily the study of an emergent community or tradition in favor of enterprising individuals. Elsewhere I have situated Christian experts of the first two centuries within the wider milieu of freelance religious expertise and proposed that their writings might shed light on the development not only of Christian forms of religion but also on phenomena that appear to have arisen from the same settings. However, the latter are not as well attested until later periods, when they had already coalesced into more institutional forms (Wendt 2016).

I wish to stress from the outset that the justification for this comparison is not simply that Christian actors and phenomena were like others in their environments, a point made repeatedly with respect to any number of characteristics; rather, it is my contention that Christians were examples, fairly unexceptional ones, of a broader swath of religious activity. In this essay I am interested generally in individual constructions of religious authority and literate intellectual practices, particularly the interpretation of "authoritative" writings and the production of new ones. Among assorted kinds of would-be religious specialists, 
textual engagement, writing, or even invoking a text notionally as the basis for one's knowledge or skills functioned as hallmarks of real expertise.

Christian writings, as a matter of their survival, constitute an especially rich literary record of this relationship between textuality and pretensions to religious authority, but they were not unique. Indeed, the sheer quantity of such literature known or known of from this period is remarkable, as are the numerous occasions on which texts that promoted individual expertise were confiscated or legislated against, with increasingly severe consequences (Sarefeld 2012; Howley 2017). Notwithstanding numerous points of contact between early Christian writers and their approximate literary contemporaries, scholars of early Christianity tend to stop short of considering the former's literature, especially (later) canonical texts, as products of the same social processes and interests that gave rise to these other texts from the same period.

In this essay my aim is thus to restore all early Christian literature to an equal footing both internally, with respect to traditional divisions between canonical and non-canonical writings, and also externally, so that it can be viewed alongside other writings seemingly implicated in a wider phenomenon of self-authorized religious expertise. My interest is ultimately less in the writings per se, than in the individual authors who composed and enlisted them. Therefore, I situate early Christian writers within a wider matrix of intellectualizing religious experts who drew on a standard repertoire of intellectual skills and habits, and, in some cases, on the same writings, to common ends. These dynamics were not exclusive to urban settings, but there is reason to think that the increasingly cosmopolitan cities of the empire furnished resources that were highly conducive to the development of religious offerings with a distinctly intellectual profile.

\section{Aspiring specialists and their texts}

In his recent book, Who Were the First Christians? Dismantling the Urban Thesis, Thomas A. Robinson calls into question what he characterizes as the "universally accepted thesis of the urban character of early Christianity, ...that Christianity was an urban religion in the first three centuries." 5 To the contrary, he argues, the empire's overall rural population so greatly exceeded the urban that "if Christianity had even a most minimal success in the countryside, gaining but a small percentage of the rural inhabitants, the number of rural Christians easily

5 The influence of the urban thesis is vast but of note are Meeks 1983; Stark, 2006; Harrison and Welborn, 2015, 2016, 2018. 
could have equaled-or indeed surpassed-that of urban Christians in the early period" (Robinson 2017: 19, cf. 39). The constant assertion of Christianity's urban profile thus risks distorting the complexion of its pre-Constantinian Christian population, which must have included a significant rural contingent in keeping with the empire's general population distribution between cities and the countryside.

One might conclude from my preliminary remarks affirming the significance of urban settings for Christian literary production that the approach I advocate in this essay sits uneasily with Robinson's important corrective; in fact, the opposite is true. What we glimpse of early "Christianity" through writings is, I suspect, a highly specialized niche within a cluster of social formations that ranged from exorcists invoking Christ, to people prophesying in his name, to semi-literate specialists who inserted him into spells or lots or horoscopes alongside other deities and sages, to voluntary associations that honored him, to more scholastic groups formed around texts featuring Christ or a cognate figure like Savior, and much more in between. That we possess and can more easily make sense of the writings may grant them far more weight, power, and representation than they actually held in this early period. It is striking that Pliny's interrogations of Christians in the second decade of the second century uncover no mention of literary engagement (Ep. 10.96.7), ${ }^{6}$ and even literate authors such as Justin hint at expressions of Christian religiosity-exorcism, in this case (2 Apol. 5.6)-that may have operated in distant relation to, if not entirely apart from, texts. ${ }^{7}$ There can be no doubt that authors of this period insist that authoritative writings were indispensable to the Christian activities they present as normative, but this is precisely what one would expect of figures operating within an intellectualizing niche who are, in essence, arguing for their own indispensability.

My main critique of Robinson's book-apart from the tricky matter of how one even identifies Christians at a time when this language is used inconsistently as a term of self-identification (Kotrosits 2015, 32-45)-is that the concept of con-

6 Pliny reports on meetings before dawn that featured singing hymns to Christ, swearing oaths, and eating. Of course, the details he reports do not preclude other activities involving texts, but these should not just be inferred for their omission from his account.

7 Although exorcism could certainly be performed in conjunction with texts, as seems to be the case in Josephus's account of Eleazar ( $A J$ 8.45-48), a renowned Judean exorcist of the Flavian period who employed in his craft incantations against illness and forms of exorcism that were

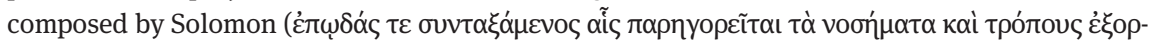

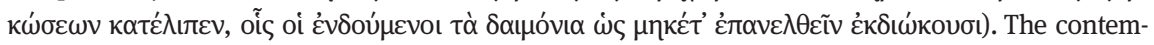
porary story appears anachronistically in the Antiquities as evidence of Solomon's great and enduring wisdom in a section that also attributes to him one thousand and five books of odes and songs and three thousand books of parables and similitudes. 
version underpinning his case for the rural dimension of Christian growth lacks this sort of differentiation, as though early Christianity was a monolithic entity whose reconstruction has suffered principally from an imbalanced topography. His arguments for the significance of rural populations in accounting for Christian numbers issue an invitation to reconsider the full range of possible "Christian" social formations in the first three centuries with a view to parsing these in accordance with the differential roles that texts might have played in their activities, if they played a role at all. ${ }^{8}$

Elsewhere I have shown that the imperial period witnessed (and also stimulated) a rise in the prominence and influence of would-be experts in all manner of specialty, including philosophy, history, rhetoric, paideia, medicine, and law (Wendt 2016; cf. Eshleman 2012). Many within this wider field of actors alleged expertise in matters of religion, in the sense that their practices, which might overlap with those of other kinds of specialists to a significant degree, are distinct for the direct involvement of and attribution of agency to gods and other divine beings. The edges between these putative areas of expertise were hazy: many experts balanced religious skills or practices with other dimensions of their programs, to greater and lesser degrees.

The expansion of religious offerings purveyed by self-authorized specialists coincided and overlapped with an effervescent literary culture at Rome and in other cities of its empire, fueled by an abundance of public and private libraries as well as a thriving commercial book industry (Johnson and Parker 2009; Johnson 2010; König, Oikonomopoulou, and Woolf 2013, esp. 279-417). In keeping with the heightened status of writing under the empire (Ando 2000; MacRae 2016; Rüpke 2016), aspiring experts of all stripes wielded sundry intellectual tools-philosophical discourses, textual exegesis, and the composition of new writings-to impress audiences who valued these offerings. In the satires of Petronius, Juvenal, Lucian, and Apuleius one observes considerable demand for the religious expert whose initiations were gleaned from ancient wisdom or prophecies, or whose healing methods aligned with contemporary currents in medicine and philosophy. While few inhabitants of the Roman world possessed the abilities required to occupy such a specialized niche, those who did wasted no opportunity to display their learning.

8 Here, I have in mind a very flexible notion of any and all social formations involving the figure of Jesus Christ, which could range from scanty references in sources such as Greek so-called magical papyri to references to exorcisms performed in Christ's name to networks comprising literate experts such as Paul or, in the second century, Justin, Ptolemy, or Marcion (Wendt 2016: 215-16). For theorization of such possibilities, see Stowers 2013. Henceforth I will use "Christian" without qualification in this broad sense. 
Religious experts with pronounced intellectual tendencies are prominent in the late Classical and Hellenistic evidence (Edmonds 2013, 112-16), but they become more visible and, evidently, more numerous under the empire. So, too, did writings that either enabled or plausibly arose from this sort of religious activity. This relationship between text and authority is evident in everything from seemingly insignificant details-Lucian's Alexander (Alex. 11) unearths an oracle, purportedly Sibylline, foretelling the advent of a prophet with his own biography, thus legitimating the establishment of his oracular temple in Abonoteichus-to the partial or full survival of collections such as the epistles of Paul and of Apollonius of Tyana, the Sibylline and Chaldean Oracles, the Orphic Rhapsodies, the Oneirocritica of Artemidorus, the Hermetica, the so-called Greek Magical Papyri, various collections of lots, and the Nag Hammadi codices (Heineman 2018). To this list should be added a number of texts that receive mention in our ancient sources, for instance, writings attributed to Pythagoras, which enjoyed renewed interest in the first centuries BCE and CE, books of the Persian sage Hystaspes (Justin, 1 Apol. 44.12), or almanacs attributed to Thrasyllus and Petosiris (Juvenal 6.575-79), famous astrologers hailing from Egypt. The dating of much of this literature is uncertain, in some cases impossible to ascertain with precision. Yet all are thought to have been composed no earlier than the first century BCE, most in the first or second centuries CE, and to have circulated within and beyond the latter window (Wendt 2016: 136-41).

In addition to texts that are either at least partially extant or mentioned in another ancient source, many authors hint at robust literatures devoted to the topics about which they write. In the preface to his own "definitive" treatment of dream interpretation, for example, Artemidorus legitimates the work to follow in contradistinction to a literary subculture that has, in his estimation, run amuck:

For nearly all our recent predecessors, perhaps wishing to achieve literary acclaim and thinking they would become famous through this alone, namely, if they left behind treatises on dream-divination, have made copies of each other's works, either expounding badly things already having been said well by the old-time authors or just adding a bunch of things that are untrue to some of the material of the old-timers. For, speaking not from experience but instead off the cuff in whatever way each of them was moved concerning some matter, so they wrote, both those having read all the books of the old-timers as well as those who have not read them all. For some of these books, having become scarce and corrupt through old age, escape their notice. But there is no book on dream-interpretation which I have not acquired, expending much zeal in this regard

(Oneir. praef.2, trans. Harris-McCoy).

Artemidorus's prefatory remarks point to a regular circulation of manuals on dream interpretation or divination that entails, in turn, the copying of both 
older and contemporary works as well as ample opportunity for interpolation or redaction. While this scene is reminiscent of ancient writing and publication practices in general, it could just as easily describe the early Christian literary landscape, most obviously, in the relationships between the Synoptic Gospels or between various Nag Hammadi writings, Genesis, and Platonic texts (Larsen 2017).

Another intriguing implication of Artemidorus's preface is that his text is not only the culmination of his own erudition, but also confers expertise on the reader who is able to employ it correctly. Radcliffe G. Edmonds III (unpublished) has advanced a similar reading of the Greek Magical Papyri, namely, that these texts were written not for clients needing to be convinced of the author's expertise but rather for potential practitioners interested in impressing their own clients. The oft-repeated insistence that the reader "will be amazed" by the outcome of a given ritual gives rise, Edmonds argues, to a feedback loop of expertise: the author may position himself as expert in relaying a spell or rite, but the reader's own competence is tested and reinforced by its proper performance. ${ }^{9}$ William Arnal (2014 and 2016) has proposed a similar reading of intellectual dynamics fostered in the Gospel of Thomas, which imposes obscurity on its cryptic logia via a series of literary techniques that function to cultivate and reinforce the reader's own sense of cultural refinement and distinction through the display of refined skills; importantly, it is the act of deploying such skills, rather than anything about the gospel's content, that produces these effects. Approaching the matter from the opposite perspective, Juvenal ridicules the woman who, having gotten ahold of an astrology almanac, "doesn't consult anyone else, but these days is consulted herself" (6.574-75). It is in a similar spirit that Irenaeus quibbles with Marcus's use of the Paignia of Anaxilaus, yet another example that underscores the ability of particular writings to weave and sustain complex webs of specialty.

It should also be said that the impetus to textualize need not correlate with literacy and often did not in the Roman world. ${ }^{10}$ While many of the writings I have mentioned, including (later) New Testament and other early Christian literature, imply fairly to highly literature authors and audiences, aspiring religious experts who were illiterate, or largely so, had several options for incorporating writing, texts, and other hallmarks of skill into their practices. For some, "writ-

9 As Edmonds (unpublished) writes, "Religious expertise is validated by an appeal to the extraordinary efficacy of the procedure, an efficacy that is proven by the reader's own experience." 10 There are also important distinctions between the functional literacy required to keep ledgers or draft receipts, for instance, and the caliber of literacy that produced the writings of present interest. 
ing" might amount to nothing more than a piece of metal inscribed with crude, nonsensical characters, but the plentiful attestation of such objects underscores its cachet among those claiming some form of religious expertise. As Richard L. Gordon $(2017,134)$ explains, “[T]here were sharp differences of perspective, aims, skills and procedures, and appeal to literate modes even within the groups we might call 'religious specialists,' none of whom would have applied the discourse(s) regarding their powers, abilities, and social standing." All, he insists, might be considered as experts in their particular domains of skill. Nor did the skills required to work with texts eclipse those for producing and manipulating other expressly extraordinary objects or "technologies for the imagination of the divine." 11 Thus, Gordon issues caution about underestimating illiterate or less literate practitioners, whose knowledge often contributed to literary treatments of their areas of specialty. ${ }^{12}$

At the same time, Gordon calls attention to various manifestations of specialization and complexity-for instance, elaborate diagrams or systems of rules for ritual performances-that fall between illiterate and highly literate forms of expertise. In contexts of acute competition, there was a premium on "highly specialised and inventive type[s] of materiality" that served as indices of skill for the specialists who wielded them while also conveying the impression that the activity in question required intricate but exact procedural knowledge. Texts constituted one such type of materiality, and one that was particularly well-suited to these performances. The more complex a writing, the more elaborate the schemes of rules or meanings that it could support, including narratives that explained and justified the need for a specialist's intervention (Gordon 2017, 141).

The urban concentration of aspiring experts in the late Hellenistic and Roman periods produced conditions for exponentially higher degrees of innovation: exposure to new discourses (astrological, philosophical, medical); access to a larger and more diverse array of material items (substances, objects, texts); competition between figures claiming expertise in the same or related domains of knowledge; and the attraction of gaining a wider reputation for expertise,

11 Gordon 2017, 138. The expression comes, however, from Daniel Miller, "Introduction," in $M a$ teriality, ed. Daniel Miller (Durham, NC: Duke University Press, 2005), 23. As Gordon writes of objects enlisted in Greco-Roman magical practice (153), "It is primarily the framing of such objects, though sometimes also their very manufacture, that simultaneously calls attention to the exceptional nature of the claims made for the knowledge that motivates their production, and the meaningfulness of that knowledge within the totality of knowledge-claims on offer."

12 As Gordon notes (2017, 143), the written herbalist-medical tradition drew heavily on the work of unknown numbers of rhizotomists and herb-sellers, almost all anonymous. 
foremost through literary production. Gordon traces an arc of increasingly textualized specialty through the last century before the Common Era and continuing through the Roman period. "Such efforts were by no means purely pragmatic," he concludes, "but appealed to the growing class of leisured readers interested in organised knowledge. Access to...books thus provided yet another way of turning material substances into ideas: substances became good to think" (Gordon 2017, 152). Nor was the impetus to specialize restricted to the realms of religious intellectual pursuits: Nicholas Purcell (1995) reconstructs a comparable trend in the Roman game of alea, a simple combination of dicethrowing and a gaming board that nevertheless acquired more and more elaborate rules and literate trappings in the urban societies where it flourished.

Although the writings I have mentioned in this section represent a wide range of aptitude, all appear to have bolstered the authority of experts acting in a freelance capacity and were indispensable to their practices. Maren R. Niehoff (2007) has suggested a simultaneous development in the formation of "textual communities" around particular corpora; her example is the Platonic corpus, above all the Timaeus. ${ }^{13}$ The Timaeus always stimulated philosophical debates about whether the cosmos were eternal or created, but in the centuries before the Common Era it served neither to define the boundaries of a particular group or philosophical school, nor as an exclusive text for Platonists that demarcated them from adherents to Aristotle (164). Interestingly, she proposes that it was Philo who, in his concern to establish a textual community around Judean "holy books" or "holy writings," elevated the Timaeus to a comparable status and defended the literal interpretation-that, as in Genesis, Platos's cosmos were created-of key passages as authoritative and true (171). For Philo, Plato -to whom Philo refers as "most holy"-"should be to the pagans what Moses was to the Jews. Plato is thus advocated as someone who wrote a text of similar

13 Niehoff borrows the phrase from B. Stock (The Implications of Literacy: Written Language and Models of Interpretation in the Eleventh and Twelth Centuries [Princeton: 1983]), who, in her words, "coined textual community to refer to groups dissenting from the mainstream and justifying their particular position by recourse to an authoritative text. This particular text was shared by society at large, but interpreted differently. The dissenting group, led by a figure with direct access to the text, formed their sense of solidarity around their particular reading" (162). Niehoff adapts the phrase to what she envisions as "an intellectual community-at-a-distance," more of a diffuse network than the quasi-monastic groups at the center of Stock's study. She also stresses that her cases are from a period in which readers of the Timaeus were in the majority and the sense of identity they formed around the text countered not a majority opinion but the claims of Christians, specifically. For a review of the use of Stock's concept in the study of antiquity, see Heath 2018. 
authority as Moses, conveying basically the same ideas as the Jewish scriptures" (173).

It is not clear whether Philo's stance was adopted more widely before the second century, but similar regard for author and text, as well as the "true opinion" on the creation question, is evident in the writings of Plutarch. Positioning himself in opposition to "most of the Platonists," Plutarch claimed to reconstruct Plato's "authentic message" by impeaching earlier and contemporary detractors from his reading as mistaken or even deceitful (An. Procr. 1012B). He also composed supplemental literature in support of his claims, two treatises and a work on Platonic questions. Thus, "by the end of the first or the beginning of the second century Plato's works, especially the Timaeus, were established as authoritative texts conveying a philosophical truth, which was faithfully transmitted by part of the Greek tradition" (Niehoff 2007, 177; cf. Hadot 2002: 148-53).

Writing against Christians in the middle part of the second century, Celsus pointedly defended what he considered to be the original meaning of the $\mathrm{Ti}$ maeus, and Platonic literature more generally, in response to Christian "misappropriations" of these texts. By placing Plato's writings at the center of his concept of "Greekness," he presented them as the boundary-marker between Christian belief and the Greek ethos, construed in kind (178). Hence, Niehoff concludes, "Celsus constructed a textual community centered on a particular approach to a specific corpus of texts. He claimed superiority of 'our' textual tradition over its Christian equivalent. The atmosphere is clearly one of competition, each community defending the value of its textual heritage and status within society at large" (178-79).

Niehoff's attention to the evolving status of the Platonic corpus traces a more general relationship between constructions of authority, textuality, and ideological concepts of community that became steadily more intertwined over the first two centuries (also Eshleman 2012). So too, did the ontology of and epistemological orientation toward certain texts begin to shift as part and parcel of this constellation, so that they were gradually granted within the social formations that developed around them a status akin to "scripture." Daniel Sarefeld finds another source of support for this scriptural trajectory in the practice of book burning, which grew increasingly prominent under the empire and, though employed on occasion by authorities of the Roman state, is also attested among "leaders of religious communities who were...engaged in local conflicts over proper beliefs and practices” (2012,163). I would reframe Sarefeld's somewhat passive characterization of these conflicts-the incidents he cites feature book burning as an aggressive assertion of authority among rival religious and/or intellectual specialists-but find the argument suggestive of how particular texts or corpora could, by the second century, operate as metonyms for the groups de- 
fined in relation to them. And while Judean and Christian intellectuals certainly contributed to all of these developments, even prominently so, their prominence cannot be reduced to a unique scriptural sensibility. Rather, these developments occurred in a climate of dynamic intellectual and literary exchange, overwhelmingly in cities, even if there was variance in the types of social formations that the texts might support on account of the differential social locations, power, and goals of the intellectuals involved.

A growing body of scholarship has emphasized the intimate contact that Christian intellectuals had not only with one another, irrespective of whether they would be coopted into later orthodox tradition or classified as heretics, but also with non-Christian intellectuals (Synder 2000, 2007, 2013; Dunderberg 2008; Eshleman 2012; Secord 2017). It is equally evident, I have argued, that self-identifying Christians had in their sights, in addition to other Christians and Jewish or Judean religious experts, magi, astrologers, myriad diviners, exorcists, healers, prophets, exegetes of prophecy, and so on (Wendt 2016, 198-202). We have only begun to appreciate the depth and significance of these affinities, that they go beyond mere resemblance and indicate instead that Christians participated in a common field of religious activity populated by assorted would-be experts, an outsized subset of which was marked by conspicuous intellectual tendencies and literary engagement. To say that Christians were merely (or even very much) like these other figures is to miss the point: they were one of many variations on the broader phenomenon. The impression that they were otherwise owes much to the calculated efforts of literate Christians, who not only formed distinct social formations-textual communities, in Niehoff's sense-predicated on specific writings and interpretations of those writings, but also, like Plutarch, wrote prolifically to authenticate their textual stances at the expense of rivals claiming the same or related literature. And despite many a claim to possess or have recovered pristine, pure, original, or authentic "traditions," all of these authors partook from a literary milieu that was inherently heterogeneous.

Heidi Marx-Wolf (2016) elaborates these latter points in her study of thirdcentury Alexandrian intellectuals, which demonstrates, very persuasively in my view, that an author's self-designation or putative affiliation-whether he or she was a Christian, a Neoplatonist, a theurgist, an Egyptian priest, a magician, and so on-were less determinative of his or her intellectual program than the specific writings that informed it. In other words, the most significant difference between a writer such as Origen and his Neoplatonic interlocutors lay in the particular literary materials that sustained their respective exegetical activities: a preference for biblical texts over Homeric (cf. Niehoff 2011). This was in keeping with the tendency of aspiring experts to concoct synthetic wisdom from ma- 
terial ranging from ancient Judean or Egyptian literature, to the writings of Plato or Hippocrates, to oracular corpora. Marx-Wolf identifies common features between the writings of Porphyry, Origen, and Iamblichus, the Nag Hammadi and (other) Platonic writings of the second and third centuries, as well as Greek so-called magical papyri. These affinities are predictable, she concludes, since many of the works in question arose, or likely did, from similar social settings: philosophical schools or circles in large urban centers that supported expansive networks of intellectual and literary exchange.

One can extend the yields of Marx-Wolf's important study to other sites of intense intellectual competition and literary production: Rome, Corinth, Smyrna, Ephesus, Jerusalem, Caesaria, Antioch, and so on. It comes as no surprise, then, that the same places were also major hubs for the publication of Christian literature (Kruger 2013; Gamble 2015). Justin's writings offer ample evidence for comparable intellectual and textual cross-pollination at Rome; he also refers with some regularity to Greek "poets," possibly the exegetes of Orphic poetry or verse oracles, and Mithras priests with knowledge of Judean prophetic texts, in addition to more obvious engagements with philosophy. A shift in focus from the specific content of such writings, including early Christian texts, to the skills, ambitions, and possible social settings of their authors allows for a more thoroughgoing redescription of religious actors who not only had many commonalities, but also viewed one another as direct competitors.

To be clear, literacy and textuality were not exclusive to urban settings; the distinctions I am advocating are not meant to replicate simplistically Robinson's urban/rural population map, with the implication that well-heeled urbanites were more drawn to intellectualizing forms of "Christianity" than simpler country folk. My point is only that the emergence of complex Christian and other religious writings can be located most plausibly in cities, especially the empire's most cosmopolitan cities, where would-be experts clustered and rife competition between them resulted in a broad spectrum of specialization and diversification. A city's "Christian" population also surely comprised multiple types of social formations, some of which were enmeshed in literate networks while others were less so or not at all. Rural areas might support some of this diversity, but they are less likely to have generated it to the same degree.

That being said, rural populations were not wholly unattuned to the notional power of writing or the prestige of bookishness and might, therefore, have been quite receptive to literate experts and writings emanating from cities, even if fewer people in the countryside possessed this caliber of literacy. It is also the case that on those occasions when early Christian writers ventured into the sticks, as it were, by establishing themselves in less urbane provinces, the places where they took up residence were not the cultural backwaters that 
scholars have tended to infer. Proffering Irenaeus as an example, Jared Secord notes that Lyons, a Latin city prone to snobbish slights, nonetheless exhibited Greek cultural aspirations, particularly among its more educated class. Rather than imagining Ireneaus's mission "among the Celts" as a brave foray into the woods, then, Secord suggests an alternative scenario $(2012,32)$ :

\begin{abstract}
Christianity had to have been introduced to Gaul from outside, and the person or people who introduced it had to have been speakers of Greek. Native residents of Gaul certainly did become Christians, but there was still a need for the sort of (Greek) expertise that could come only from larger centers of Christian teaching, such as Rome. There is a clear precedent for this model in the practice described by Strabo of the Gauls welcoming and hiring Greek sophists and doctors to become residents of their cities and to work in them. A Greek doctor, Alexander of Phrygia, was even one of the Christians martyred at Lyons. In this sense, Irenaeus was perhaps a different sort of Greek expert encouraged or even invited to come to Lyons.
\end{abstract}

What Secord's astute reframing makes clear is, on the one hand, that even less obvious areas of the empire-places without reputations as cultural hubsstrived to court and cultivate Greek intellectual life (which included religious intellectuals, among them Irenaeus), and, on the other, that more cosmopolitan cities, Rome in particular, served as hubs for the formation or refinement of would-be experts who might later fan outward to regions less cluttered with competition; many, as had Justin and Irenaeus, had already relocated to the capital from another provincial city.

It stands to reason that writings followed the same pattern, taking shape in urban milieus as artifacts of intellectual competition that could be disseminated more widely. Such a picture arises in the Shepherd of Hermas (Vis. 2.4.3), whose eponymous author is instructed in a vision to copy a mysterious text and then send an additional copy of his little book to Clement, whose duty is to send it to "the cities abroad," while keeping his own copy to read "in this city" (Rome). This Christian anecdote has a centripetal counterpart in the report that Juba II of Mauretania was in the habit of traveling to Rome to peruse its famous collection of Pythagorean pseudepigrapha, which he was keen to amass (Wendt 2016, 122 n. 28). In both examples the capital emerges as a place known for literary production, the point of origin for a wider dissemination of texts.

The trend of fashioning expertise increasingly along intellectual lines was not exclusive to but was especially pronounced in cosmopolitan cities, which boasted a number of resources that contributed to it: the widespread availability of texts; numerous mechanisms and venues that promoted literary exchange; and a general enthusiasm for forms of religion with a textual or intellectual 
bent; to say nothing of background factors such as population density and heterogeneity. Sorting the participants in this sort of religious activity into distinct categories-Judaism, Christianity, Gnosticism, magic, mystery cults, or philosophy-on the basis of their textual proclivities or select features of their practices masks any number of resemblances between them that stemmed from reliance on the same urban resources and networks.

\section{Christian literature as witness}

The methodological reorientation that I outlined in the preceding section stands to improve our reconstruction of its broader religious landscape in at least two ways, one specific to the Christian evidence and the other less so.

First, imagining early Christian literature, both canonical and non-canonical, doing work in the service of interested authors and audiences encourages us to move beyond a cataloguing of resemblances between Christians and contemporaneous social actors toward a theorization of Christians among other experts for whom literary composition and interpretation furthered various ambitions: to display and safeguard religious authority; to elevate one's own expertise above that of assorted rivals; to cater to widespread interest in religious offerings that required and rewarded the skills of their audiences; and to form various types of groups dedicated to one's particular teachings and practices. These considerations promote a more plausible account of why and to what ends at least some early Christians wrote and interpreted texts, one that also explains similarities between their writings and others that did similar work. The second gain is that restoring Christian literature to this literary landscape allows these plentifully attested writings to be mined for insight into more shadowy religious developments occurring simultaneously within the same field of religious activity.

Regarding the first matter, namely, of how the approach that I have advocated in this paper stands to reorient scholarly inquiry into the origins and development of Christianity as reflected in its literature, I propose the following: viewing this literature as artifacts of religious competition that was taking place apart from (and prior to) the existence of Christian institutions puts considerable pressure on the exceptional history that is told through the same texts. Earlier I noted that the analytical turn to individual agency in the study of ancient Mediterranean religion has not been fully absorbed in the study earliest Christianity, especially (later) New Testament literature. This is, in part, because traditional narratives about its origins and spread tend to posit pious religious communities, and networks of such communities, as the most elemental social formations compris- 
ing the movement (Stowers 2013; Urciuoli 2013). ${ }^{14}$ Where individuals or individual interests do factor into this account, they stand in tension with Christian communities, or the authoritative tradition that the communities preserved.

Support for this logic is ample in early Christian literature, for example, in Irenaeus's complaint that each so-called heretic "claims as this wisdom-(the secret wisdom Paul taught only 'among the mature' [1 Cor 2:16]) - that which he discovers by himself, which is really a fiction, so that their truth may fittingly be in Valentinus at one time, at another in Marcion, at another in Cerinthus, finally in Basilides, or even in one who disputes against these and would not be able to say anything pertaining to salvation. For each one of them, being totally corrupt, is not ashamed to deprave the rule of truth and preach himself" (Haer. 3.2.1, trans. Unger). Here and elsewhere in "proto-orthodox" literature, a or the "Church" is the shadowy negative image of problematic exercises of individuality: its actuality and integrity are, for scholars, implicit in anxiety about atomization. However, the trail of evidence for earliest Christianity leads necessarily to individuals, authors, whose relationship to actual groups is another matter from the corporate and institutional rhetoric they employ.

Nevertheless, it is from this evidence that scholars have extrapolated fully formed religious communities and traditions whose hypothetical status, once posited, not only obscures other social settings from which early Christian literature might have arisen, but also renders Christians incomparable to non-Christian (and non-Jewish) religious actors and groups of the Greco-Roman world. Nowhere are these observations more apparent than in scholarship on the fourfold gospel, another Irenaean legacy that stresses the collective witness of these writings over and against the singular gospels of his opponents. Irenaeus's presentation of these texts as a synthetic (even natural) testament to a unitary Christian tradition mimics the same corporate-versus-individual logic.

And yet, as recent publications remind us, there is no incontrovertible evidence that the canonical gospels were written prior to the mid-second century, when there is suddenly quite a lot. Nothing about this textual lacuna is revealing at its face. However, Markus Vinzent has taken the absence of reliable early witnesses to gospel literature as a point of departure for the intriguing thesis that the concept of a written gospel did not emerge until Marcion composed his Evangelion, which then provoked responses in kind from his literate Christian rivals

14 Both Stowers and Urciuoli offer insight into the intellectual history and offer persuasive critiques of this concept of Christian community, applied uniquely to the Christian evidence, which does very different historiographic work than the sociological model of textual communities developed by Niehoff 2007 and Johnson 2010. 
(Vinzent 2011 and 2014). ${ }^{15}$ As one would expect in competing classrooms in a city," Vinzent explains, "Marcion's venture was soon replicated by other teachers who contributed, altered, broadened, or nuanced both the [Pauline] letters and [his] Gospel according to their respective needs and interests" (2011, 88). Vinzent presumes a high degree of mutual awareness and exchange among would-be Christian authorities of the mid-second century, all of whom were active at Rome. Hence the capital emerges in Vinzent's account as the likeliest setting for much early Christian literary composition, and its abundant intellectual resources as the armature that supported these efforts.

It remains to be seen how many will be persuaded by Vinzent's arguments, but some of the planks of thesis gain strength from consideration of the broader social context for which I have argued above. In light of analogous instances of literary production-for instance, texts that were written about, or attributed to Pythagoras, Abraham, Moses, Solomon, Epicurus, Zoroaster, Apollonius, and so on-it is certainly worth considering whether the composition of gospel literature, both canonical and non-canonical, amounted to a tactic that rival Christian experts enlisted to undermine one another's authority as they legitimated their own. There are numerous indications to support this general picture, including at least one canonical gospel author, Luke's, apparent reliance on the writings of Josephus (Mason 2003). Other signatures of intellectual competition play out through all four New Testament gospels, above all the literary dependence between Mark, Matthew, and Luke, which makes a good deal of sense as an outcome of rivalry among intimate, literate rivals.

Drawing gospel composition into the general fold of freelance religious expertise does not require a second-century date for the (later) canonical texts, but there are clues that points in this direction. Notably, Paul neither attributes any teachings to Jesus, nor characterizes Jesus as a teacher; his focus falls instead on how "the writings" or "oracles of God," properly interpreted with the benefit of pneumatic discernment, reveal divine wisdom about Christ. Justin strengthens the connection between Judean prophecy and Jesus Christ through a series of fulfillment citations, while also introducing Jesus's own logoi (especially, 1 Apol. 32.1-42.1); for corroboration, he directs his readers to certain apos-

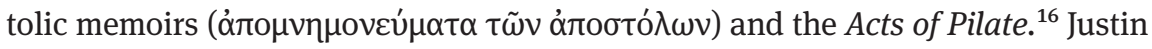

15 On the priority of a gospel used and broadcast, although not written, by Marcion, see also Klinghardt (2008 and 2015).

16 Cosgrove 1982. The language occurs twice in Justin's 1 Apology, 66.3 and 67.3, and thirteen times in the Dialogue with Trypho, all in chapters 99-107, where Justin cites the circumstances and events of the crucifixion as proof they have fulfilled the "oracular" criteria of Ps 21. One additional reference to the "memoirs" is found in Dial. 100.4, where Justin indicates that these writ- 
may be a reliable witness to written traditions about Jesus, but it is far from certain that he regards such writings as scripture. It is equally possible that his apparent knowledge of gospel material stems from texts not yet in existence, but only then taking shape, maybe even within his own intellectual circle at Rome.

By the time that Irenaeus writes, there is a much stronger relationship between teachings and stories associated with Jesus, and the kinds of contemporary practices that such writings might authorize. Among the many complaints that he registers against heretical teachers and groups, Irenaeus's greatest and most pervasive grievance involves the vulnerability of Christian writings to "manipulation.” This language is consistent with how he characterizes the textual practices and character of all heretical teachers: in terms of corruption, adulteration, perversion, falsification, divergence, and innovation. These concepts suggest explicitly that what unites heretics is a disregard for the integrity of authoritative texts and the tradition that precedes them, and implicitly that the writings in question exist, and have long existed, in pure and unadulterated forms.

Irenaeus labors to create the impression that the Christian literary landscape can be broken down into three classes of writings: the first consists of authentic texts, whose reliability and legitimacy are confirmed by the status of their authors; the second consists of corrupted versions of authentic writings, that have been rearranged, reworded, reinterpreted, and so forth in accordance with the interests of various heretical interpreters; while the third consists of entirely new texts that are tailored to the interests and practices of contemporary authors. $^{17}$

Scholars have been reticent to challenge the basic elements of this "proto-orthodox" gospel scheme, with the result that the sort of literary taxonomy we encounter in Irenaeus's writings continues to be reinscribed in our scholarly categories and disciplinary sub-divisions even as other elements of his discursive practices have been reoriented (Brakke 2012). It is largely accepted that his preferred gospels (versions of which will become the canonical gospels) contain traditions that are early and reliable (or more reliable), and that these traditions acquired written form through disinterested processes, namely, as the result of Christian community needs. It is likewise accepted on Irenaeus's authority that "heretics" both manipulated versions of the canonical gospels and also

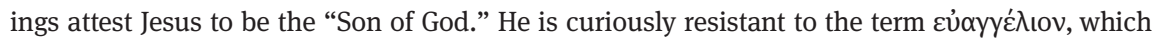

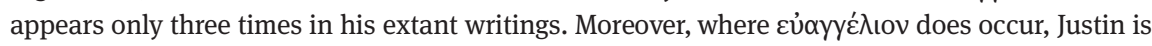
careful to decouple this concept from the apostolic writings to which he refers on other occasions.

17 Articulations of this logic are scattered throughout the text; for poignant distillations, see esp. Haer. 1.8.1; 3.1-3.4; 3.11.7-9. 
made up their own gospels from whole cloth. With the focus shifted to the textual practices of these rival Christian experts, and with a view to the use of writings within the wider context of freelance expertise, it is worth considering that even the canonical were in the process of being written to support particular positions as opposed to the other way. It is noteworthy that many of the practices criticized in second-century sources-mythmaking, genealogical speculation, the ongoing exegesis of oracular Judean texts (e.g., 1 Tim 1:3-7, 5:3-5; 2 Tim 4:3-4; Tit 1:13-14, 3:8-9)-feature as prominently in the fourfold gospel as they do in non-canonical texts.

Beyond these possibilities in the narrower study of early Christianity, I indicated that redescribing Christian writings as evidence for the religion of self-authorized experts, more generally, may offer new avenues of explanation for other religious phenomena that seem to have emerged from this context. There is considerable room for developing this second suggestion with respect to particular bodies of evidence but, given spatial limitations, I will only gesture toward such possibilities with respect to a single comparandum, religious offerings that featured Mithras.

I highlight this example for two reasons: First, there is a considerable lag between our earliest literary and epigraphic references to Mithras, which come in the last decades of the first century CE, and the earliest mithraea, which, at least in Rome and Ostia, are not attested before the third century (Gordon 1972; White 2012). This timeframe coincides roughly with, on the early end, the Pauline Epistles and the first external witnesses to Christ devotion and the emergence of Christian material cultural evidence no earlier than the third century. It is apparent from the regularity of Mithraic image programs and gathering spaces that the intervening century witnessed the consolidation of some institutionalized version of Mithras cult (Gordon 2007). Similar processes can be seen occurring in and by means of Christian literature dated confidently to the second century.

The full body of evidence for Mithras devotion comprises fresco and sculptural programs, references to the god in the Greek Magical Papyri, including the so-called "Mithras liturgy" (Betz 2003), depictions of him on amulets and gemstones (Mastrocinque 1998), scores of altars and other dedications, various epigraphic texts, and mention of his priests and devotees in scattered literature, in addition, of course, to mithraea. That his mysteries proper were conveyed through the adapted medium of astrology has led many to suspect they originated from intellectual circles (Ulansey 1991), maybe even, as Roger Beck has postulated, in the immediate circle of the court astrologer, Ti. Claudius Balbillus, thought to be the son of the aforementioned Thrasyllus (Beck 1998 and 2004). 
What we lack for Mithras is the sort of literary evidence that discloses, in grainy detail, how phenomena involving the figure of Christ fractured, coalesced, and acquired regular institutional features over the course of at least two centuries, before eventually imprinting the archaeological record. I see every indication that these processes unfolded in both cases within the context of self-authorized religious expertise. Furthermore, there is an intriguing parallel in evidence for Persian and Judean religious experts early in the first century and the emergence of Mithras and Christ devotion in its final decades. Numerous references to magi at Rome-a term that retained connotations of Persian religious expertise through most of the first century (Rives 2010)-occur in early imperial literature. They appear time and again in stories of Roman aristocrats tried for consulting them about sensitive political matters; in various expulsions issued during this period; and in Suetonius' report that the emperor Nero had undergone rites of the magi, a rumor to which Pliny assigns a specific magus, Tiridates, who traveled with other magi to Rome in order to initiate Nero and instruct him in their arts ( Nat. 30.14-17; also Suetonius, Ner. 13.11, 30.22).

Locating the origins of Mithras religion within the context of freelance expertise accounts for the apparent Roman origins and range of evidence for this deity, some of which bears no obvious relationship to the activities posited for mithraea. Instead of presuming that such artifacts were derivative of Mithras cult as it has been reconstructed from archaeological contexts, it seems worthwhile to explore the possibility that all of this evidence attests ongoing configurations of Mithras offerings taking shape among experts of differing abilities, interests, and settings and gaining traction among different types of social formations, eventually, voluntary associations that could finance dedicated meeting spaces. If there is any merit to this suggestion, patterns and dynamics that emerge from Christian sources might be useful for filling in some of the gaps in the parallel development of these forms of religion.

Apropos of that proposal are a handful of references to Mithras and in the writings of Justin. In his Dialogue with Trypho, he writes, "Now, when those who transmit the mysteries of Mithras claim that he was born of a rock, and call the place where they initiate his believers a cave, am I not right in concluding that they have imitated that saying of Daniel, 'A stone was hewn without hands out of a great mountain (Dn 2:34)?' In a similar fashion, have they not attempted to imitate all the sayings of Isaiah?” (Dial. 70.1, trans. Falls). Justin then quotes Isaiah 33.13-19, concluding that it obviously foreshadows Christ, and none other (70.2-4). He returns to this point, insisting, "By these words the priests who perform the mysteries of Mithras were urged by the devil to declare that they were initiated by Mithras himself in a place they call a cave" (78.6). 
While one might rightly be skeptical of Justin's claim that Mithras initiators found evidence for their god in Isaiah, here and elsewhere he invokes as his principal rivals not an exclusive, undifferentiated swath of Judeans and contrary Christians, as one might expect, but assorted actors with his intellectual druthers. There is, apart from inscriptions and occasional references to Mithras in spells, an absence of more complex Mithraic literature, although this does not foreclose the possibility that, as some have conjectured, such a literature once existed. Justin's references suggest, however, that he viewed Mithras priests or initiators as opponents in kind and connected them with literary exegesis; whether they actually knew Isaiah matters less than Justin's sense of his claim's plausibility. Here and elsewhere, fleeting glimpses of "Persian" experts and texts suggest processes, practices, diversity, and rivalries that concur with dynamics pervasive in Christian literature of the second century. If all these actors-Justin, Marcion, Valentinus, Irenaeus, Marcus, and possibly even the authors of the four gospels-are theorized as examples of the religious experts who were commonplace in cities of the imperial period, then Christian literature, restored to this context, stands to shed light on this particular dimension of the empire's evolving religious culture.

\section{Conclusions}

In this essay, I have attempted to illustrate how a particular form of religious activity offers a plausible social setting for theorizing the emergence, development, and ongoing diversification of Christian forms of religion. I have suggested that our earliest evidence for Christian experts, texts, and social formations, maps onto an earlier and more capacious class of religious activity, one area of which consisted of writer-intellectuals, while other areas comprised non-textual diviners, inspired prophets, exorcists, and even authorities on Christ whose practices might not emphasize writings much or at all.

To theorize Christian intellectuals and texts as variations on a wider phenomenon permits more thoroughgoing and creative comparisons with contemporaneous actors, groups, and writings. It strikes me as a promising exercise to map texts seemingly implicated in this sort of religious activity along a vertical axis in accordance with degrees of aptitude, requisite levels of literacy, specialized training, and intellectual backdrops, so that complex writings cluster at one pole, and the most basic ones at the other. This way of arranging the evidence has the advantage of then throwing into relief horizontal textual relationships at particular literary registers, for instance, as Ismo Dunderberg (2008) has demonstrated, between Valentinian and Hermetic literatures. 
With the materials arranged in this way it is easier to see how particular kinds of writings worked to construct and foster dependence on specialty or to engender particular social formations: occasional client or pedagogic relationships, schools of instruction, initiation circles, voluntary associations, private temples and even the independent acquisition of wisdom or skills. It also expresses these possibilities without implying from the outset essential differences between the texts, authors, readers, or groups. Finally, and perhaps counter-intuitively, this approach reminds us of the representative limits of the literary record. That the triumph of Christianity was as much a triumph of literate religious specialists all but guaranteed the pride of place texts would occupy in post-Constantinian historiographies of the movement. ${ }^{18}$ Just as competing claims to the "authentic" Platonic legacy should not be taken as straightforwardly representative of "Platonism," "philosophy," "the Greek ethos," or "Greek theology," neither were the self-positionings of literate Christian experts or Christian texts necessarily, or likely, representative of the full landscape of "Christianity" in this period

\section{Bibliography}

Ando, Clifford. Imperial Ideology and Provincial Loyalty in the Roman Empire. Berkeley: University of California Press, 2000.

Arnal, William. "Blessed Are the Solitary: Textual Practices and the Mirage of a Thomas 'Community."' In The One Who Sows Bountifully: Essays in Honor of Stanley K. Stowers, edited by Caroline Johnson Hodge, Saul M. Olyan, Daniel Ullucci, and Emma Wasserman, 271-81. Brown Judaic Studies 356. Atlanta: SBL Press, 2014.

Arnal, William. "How the Gospel of Thomas Works." In Scribal Practices and Social Structures among Jesus Adherents: Essays in Honour of John S. Kloppenborg, edited by William Arnal, Richard Ascough, Robert Derrenbacker, and Philip Harland, 261-80. Leuven: Peeters, 2016.

Beck, Roger. "The Mysteries of Mithras: A New Account of their Genesis." The Journal of Roman Studies 88 (1998): 115-28.

Beck, Roger. "Whose Astrology? The Imprint of Ti. Claudius Balbillus on the Mithraic Mysteries." In Beck on Mithraism: Collected Works with New Essays, 323-29.

Burlington: Ashgate, 2004.

Betz, Hans Dieter. The Mithras Liturgy: Text, Translation, and Commentary. Tübingen: Mohr Siebeck, 2003.

Berzon, Todd S. Classifying Christians: Ethnography, Heresiology, and the Limits of Knowledge in Late Antiquity. Berkeley: University of California Press, 2016.

18 For the tendency to overemphasize the textual profile of early Christianity in the pre-Constantinian period, see Stowers 2016 and 2019. 
Brakke, David. The Gnostics: Myth, Ritual, and Diversity in Early Christianity. Cambridge, MA: Harvard University Press, 2012.

Cosgrove, Charles H. "Justin Martyr and the Emerging Christian Canon: Observations on the Purpose and Destination of the Dialogue with Trypho." Vigiliae Christianae 36 (1982): 209-32.

Davidson, James N. “Don’t try this at home: Pliny's Salpe, Salpe’s Paignia and Magic.” Classical Quarterly 45 (1994): 590-92.

Dickie, Matthew W. Magic and Magicians in the Greco-Roman World. New York: Oxford University Press, 2001.

Dunderberg, Ismo. Beyond Gnosticism: Myth, Lifestyle, and Society in the School of Valentinus. New York: Columbia University Press, 2008.

Edmonds, Radcliffe G., III. "And You Will Be Amazed: The Rhetoric of Authority in the Greek Magical Papyri." Unpublished paper presented at "Colloquium in Response to Heidi Wendt's At the Temple Gates: The Religion of Freelance Experts in the Roman Empire." Ohio State University, Columbus, OH. September 30, 2017.

Edmonds, Radcliffe G., III. Redefining Ancient Orphism: A Study in Greek Religion. Cambridge: Cambridge University Press, 2013.

Eshleman, Kendra. The Social World of Intellectuals in the Roman Empire: Sophists, Philosophers, and Christians. Cambridge: Cambridge University Press, 2012.

Gamble, Harry Y. "The Book Trade in the Roman Empire." In The Early Text of the New Testament, edited by Charles E. Hill and Michael J. Kruger, 23-36. New York: Oxford University Press, 2012.

Gordon, Richard L. "Mithraism and Roman Society.” Religion 2 (1972): 92-121.

Gordon, Richard L. "Institutionalized Religious Options: Mithraism." In A Companion to Roman Religion, edited by Jörg Rüpke. Oxford: Blackwell, 2007.

Gordon, Richard L. "From Substances to Texts: Three Materialities of Magic in the Roman Imperial Period." In The Materiality of Magic, edited by Dietrich Boschung and Jan N. Bremmer, 133-76. Paderborn: Wilhelm Fink, 2017.

Hadot, Pierre. What Is Ancient Philosophy? Translated by Michael Chase. Cambridge: Harvard University Press, 2002.

Harris-McCoy, Daniel. E. Artemidorus' Oneirocritica: Text, Translation, and Commentary. Oxford: Oxford University Press, 2012.

Harrison, James R. and L. L. Welborn, eds. The First Urban Churches, vol. 1-3. WGRW Suppl. 7-9. Atlanta: SBL Press, 2015-2018.

Heath, Jane. “'Textual Communities': Brian Stock's Concept and Recent Scholarship on Antiquity." In Scriptural Interpretation at the Interface between Education and Religion: In Memory of Hans Conzelmann, edited by Florian Wilk, 5-35. Themes in Biblical Narrative 22. Leiden: Brill, 2018.

Heineman, Kristin M. The Decadence of Delphi: The Oracle in the Second Century AD and Beyond. New York: Routledge, 2018.

Howley, Joseph A. "Book Burning and the Uses of Writing in Ancient Rome: Destructive Practice Between Literature and Document.” The Journal of Roman Studies 107 (2017): $213-36$.

Irenaeus. Against the Heresies, I-III. Translated and annotated by Dominic J. Unger. Ancient Christian Writers 55, 64-65. New York: Paulinist, 1992 and 2012. 
Johnson, William A. Readers and Reading Culture in the High Roman Empire: A Study of Elite Communities. New York: Oxford University Press, 2010.

Johnson, William A. and Holt N. Parker, eds. Ancient Literacies: The Culture of Reading in Greece and Rome. New York: Oxford University Press, 2009.

Justin Martyr. Dialogue with Trypho. Translated by Thomas B. Falls. Washington, D.C.: The Catholic University of America Press, 2003.

Klinghardt, Matthias. Das älteste Evangelium und die Entstehung der kanonischen Evangelien. Tübingen: Francke Verlag 2015.

Klinghardt, Matthias. "The Marcionite Gospel and the Synoptic Problem: A New Suggestion." Novum Testamentum 50 (2008): 1-27.

König, Jason, Katerina Oikonomopoulou, and Greg Woolf, eds. Ancient Libraries. Cambridge: Cambridge University Press, 2013.

Kotrosits, Maia. Rethinking Early Christian Identity: Affect, Violence, and Belonging. Minneapolis: Fortress, 2015.

Kruger, Michael J. "Manuscripts, Scribes, and Book Production within Early Christianity." In Social and Literary Contexts for the New Testament, edited by Stanley E. Porter and Andrew W. Pitts, 15-40. Leiden: Brill, 2013.

Larsen, Matthew D.C. "Accidental Publication, Unfinished Texts, and the Traditional Goals of New Testament Textual Criticism.” Journal for the Study of the New Testament 39 (2017): 362-87.

Marx-Wolf, Heidi. Spiritual Taxonomies and Ritual Authority: Platonists, Priests, and Gnostics in the Third Century C.E. Divinations. Philadelphia: University of Pennsylvania Press, 2016.

Mason, Steve. Josephus and the New Testament. Peabody, MA: Henderson, 2003.

Mastrocinque, Attilio. Studi sul Mitraismo: il Mitraismo e la Magia. Rome: Giorgio Bretschneider, 1998.

Meeks, Wayne. The First Urban Christians: The Social World of the Apostle Paul. New Haven: Yale University Press, 1983.

Niehoff, Maren R. “Did the Timaeus Create a Textual Community?" Greek, Roman, and Byzantine Studies 47 (2007): 161-91.

Niehoff, Maren R. Jewish Exegesis and Homeric Scholarship in Alexandria. New York: Cambridge University Press, 2011.

Purcell, Nicholas. "Literate Games: Roman Urban Society and the Game of Alea." Past \& Present 147 (1995): 3-37.

Rives, James. "Magus and its Cognates in Classical Latin." In Magical Practice in the Latin West: Papers from the International Conference Held at the University of Zaragoza 30 Sept.-1 Oct. 2005, edited by Richard L. Gordon and Francisco Marco Simón, 53-77. RGRW 168. Leiden: Brill, 2010.

Robinson, Thomas A. Who Were the First Christians? Dismantling the Urban Thesis. New York: Oxford University Press, 2017.

Rüpke, Jörg. On Roman Religion: Lived Religion and the Individual in Ancient Rome. Townsend Lecture Series/Cornell Studies in Classical Philology. London: Cornell University Press, 2016.

Rüpke, Jörg, ed. The Individual in the Religions of the Ancient Mediterranean. Oxford: Oxford University Press, 2013. 
Rüpke, Jörg and Wolfgang Spickermann, eds. Reflections on Religion Individuality: Graeco-Roman and Judaeo-Christian Texts and Practices. RVV 62. Berlin: De Gruyter, 2012.

Sarefeld, Daniel. "The Symbolics of Book Burning: The Establishment of a Christian Ritual of Persecution." In The Early Christian Book, edited by William E. Klingshirn and Linda Safran. CUA Studies in Early Christianity. Washington, D.C.: The Catholic University of America Press, 2012.

Secord, Jared. "The Cultural Geography of a Greek Christian: Irenaeus from Smyrna to Lyons." In Irenaeus: Life, Scripture, Legacy, edited by Sara Parvis and Paul Foster, 25-34. Minneapolis, MN: Fortress, 2012.

Secord, Jared. "Irenaeus at Rome: The Greek Context of Christian Intellectual Life in the Second Century." In Irénée entre Asie et Occident, edited by Agnès Bastit-Kalinwoska, 1-20. Turnhout: Brepols, 2017.

Snyder, H. Gregory. Teachers and Texts in the Ancient World: Philosophers, Jews, and Christians. Religion in the First Christian Centuries. London: Routledge, 2000.

Snyder, H. Gregory. “'Above the Bath of Myrtinus': Justin Martyr's 'School' in the City of Rome," Harvard Theological Review 100: 335-62.

Snyder, H. Gregory. "The Classroom in the Text: Exegetical Practices in Justin and Galen," in Christian Origins and Greco-Roman Culture." In Social and Literary Contexts for the New Testament, edited by Stanley E. Porter and Andrew W. Pitts, 663-85. Leiden: Brill, 2013.

Stark, Rodney. Cities of God: The Real Story of How Christianity Became an Urban Movement and Conquered Rome. San Francisco: HarperSanFrancisco, 2006.

Stowers, Stanley. "The Concept of 'Community' and the History of Early Christianity." Method and Theory in the Study of Religion 23 (2013): 238-56.

Stowers, Stanley. "Why Expert versus Nonexpert Is Not Elite versus Popular Religion: The Case of the Third Century." In Religious Competition in the Greco-Roman World, edited by Nathaniel DesRosiers and Lily Vuong, 139-54. Atlanta: SBL Press, 2016.

Stowers, Stanley. "Locating the Religion of Associations." In Remaking the World: Christianity and Categories. Essays in Honor of Karen L. King, edited by Taylor G. Petrey et al., 301-24. WUNT 434. Tübingen: Mohr Siebeck, 2019.

Ulansey, David. The Origins of the Mithraic Mysteries: Cosmology and Salvation in the Ancient World. New York: Oxford University Press, 1991.

Urciuoli, Emiliano Rubens. "La comunità ubiqua: Considerazioni sull'onnipresenza comunitaria nella storia del cristianesimo antico." Studi e Materiali di Storia delle Religioni 79 (2013): $557-83$.

Vinzent, Markus. Christ's Resurrection in Early Christianity and the Making of the New Testament. Surrey: Ashgate, 2011.

Vinzent, Markus. Marcion and the Synoptic Gospels. Studia Patristica Suppl. 2. Leuven: Peeters, 2014.

Wendt, Heidi. At the Temple Gates: The Religion of Freelance Experts in the Roman Empire. New York: Oxford University Press, 2016.

White, L. Michael. "The Changing Face of Mithraism at Ostia: Archaeology, Art, and the Urban Landscape." In Contested Spaces: Houses and Temples in Roman Antiquity and the New Testament, edited by David L. Balch and Annette Weissenreider. WUNT 285. Tübingen: Mohr Siebeck, 2012. 
